\title{
Maxillary Sinus Cancer pTX TNM Finding v6 and v7
}

National Cancer Institute

\section{Source}

National Cancer Institute. Maxillary Sinus Cancer pTX TNM Finding v6 and v7. NCI

Thesaurus. Code C64753.

Maxillary sinus cancer in which the primary tumor cannot be assessed. (from AJCC 6th and 7th Eds.) 